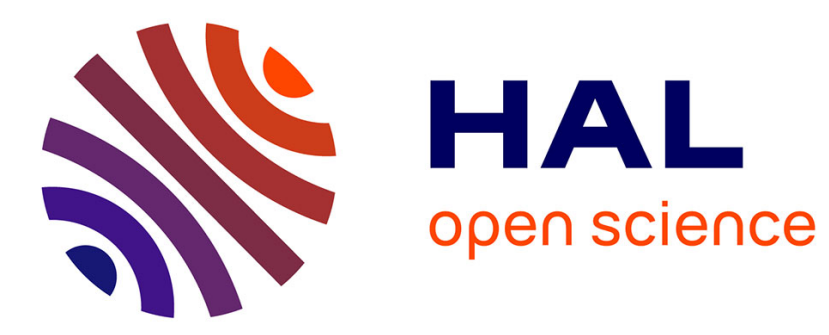

\title{
Economic Rationales of Exclusive Dealing; Empirical Evidence from the French Distribution Networks
}

\author{
Muriel Fadairo, Jianyu Yu
}

\section{To cite this version:}

Muriel Fadairo, Jianyu Yu. Economic Rationales of Exclusive Dealing; Empirical Evidence from the French Distribution Networks. 2014. halshs-00945551

\section{HAL Id: halshs-00945551 \\ https://shs.hal.science/halshs-00945551}

Preprint submitted on 12 Feb 2014

HAL is a multi-disciplinary open access archive for the deposit and dissemination of scientific research documents, whether they are published or not. The documents may come from teaching and research institutions in France or abroad, or from public or private research centers.
L'archive ouverte pluridisciplinaire HAL, est destinée au dépôt et à la diffusion de documents scientifiques de niveau recherche, publiés ou non, émanant des établissements d'enseignement et de recherche français ou étrangers, des laboratoires publics ou privés. 
Economic Rationales of Exclusive Dealing; Empirical Evidence from the French Distribution Networks

Muriel Fadairo, Jianyu Yu 


\section{GATE Groupe d'Analyse et de Théorie Économique Lyon-St Étienne}

93, chemin des Mouilles 69130 Ecully - France

Tel. +33(0)4 72866060

Fax $+33(0) 472866090$

6, rue Basse des Rives 42023 Saint-Etienne cedex 02 - France

Tel. +33 (0)4 77421960

Fax. +33 (0)4 77421950

Messagerie électronique / Email : gate@gate.cnrs.fr

Téléchargement / Download : http://www.gate.cnrs.fr - Publications / Working Papers 


\section{Economic Rationales of Exclusive Dealing; Empirical Evidence from the French Distribution Networks ${ }^{1}$}

\author{
Muriel Fadairo \\ Université de Lyon, Lyon F- 69007, France \\ CNRS, GATE L-SE, Ecully, F- 69130, France \\ Université J. Monnet, Saint-Etienne, F- 42000, France \\ muriel.fadairo@univ-st-etienne.fr
}

\author{
Jianyu $\mathrm{Yu}$ \\ Research Institute of Economics and Management, \\ Southwest University of Economics and Finance, \\ Chengdu, Sichuan, China, 610074 \\ yujianyu@swnfe.edu.cn
}

\section{ABSTRACT}

This paper investigates the rationales of exclusive dealing (ED), which is one of the most common forms of vertical restraint and attracts intense policy debates in anti-trust regulations. Based on a survey of the theoretical literature, we derive several hypotheses relative to the anti- and pro-competitive motivations of ED. These hypotheses are submitted to French data regarding several types of distribution networks in a wide range of sectors. Considering the industry features, our empirical analysis indicates that in the French distribution system, ED contracts tend to be procompetitive. The evidence suggests that the motivation of ED mainly lies in its positive role to foster the investment of upstream firms.

Keywords: Exclusive dealing; Vertical restraints; Competition policy

JEL Classification Numbers: C12; L42.

\footnotetext{
${ }^{1}$ We are grateful to the French National Institute of Statistics and Economic Studies (INSEE) for allowing use of its original dataset. We also thank Laure Turner (INSEE) and Emilie Dargaud (GATE L-SE) for helpful discussions and valuable advice. All errors are ours.
} 


\section{Introduction}

As one of the most common forms of vertical restraint and as a prevalent device in franchising networks, exclusive dealing (ED) has been attracting the attention of industry players and competition policy authorities for decades (Lafontaine and Slade, 2012).Vertical restraints are contractual provisions imposed by a producer to constrain the action of one or several retailers. ED clauses, as components of contracts between manufacturers and distributors, require the purchase of products or services exclusively from only one supplier for a period of time. These agreements prohibit the distributor from carrying the products of rival manufacturers.

The regulations in the United States (US) and in the European Union (EU) were traditionally hostile to these restrictions and were viewed with suspicion. This position has evolved over time.

Currently, the French legal environment regarding vertical restraints is defined by the Treaty on the Functioning of the European Union (TFEU). Article 101(1) of the Treaty prohibits agreements that prevent, restrict or distort competition. However, agreements that create sufficient benefits to outweigh the anti-competitive effects are exempt from this prohibition under Article 101(3) of the TFEU. In addition, the European Commission has adopted the Block Exemption Regulation (BER) on vertical restraints, which entered into force on June 2010 and will remain in force until May 2022 (Regulation (EU) No 330/2010). This regulation provides a safe environment for most vertical agreements, including ED. It renders, by block exemption, the prohibition of Article 101(1) of the TFEU inapplicable to vertical agreements that fulfil certain requirements. Franchising is not specifically mentioned in the regulation itself, but is dealt with in the guidelines on vertical restraints (SEC (2010) 411). These guidelines describe the approach taken towards vertical agreements not addressed by the BER. In particular, the BER does not apply if the market share of the supplier and/or buyer exceeds $30 \%$. However, exceeding the market share threshold of $30 \%$ does not create a presumption of illegality as this threshold serves only to distinguish those agreements that benefit from a presumption of legality from those that require an individual examination ${ }^{2}$.

Indeed, as for the other vertical restraints, the anti-trust effects of ED are complex and appear as a main controversial issue in the courts and among economists. For example, studying the ED case of Ticketmaster in Ireland, Gorecki (2006) uses two distinct methods. In so doing, he arrives at opposite conclusions on the abuse of a dominant position of the company. For this reason, most economists consider that the rule of reason approach is better than a per se prohibition and should be generalised, as it allows assessing for each case if the pro-competitive impacts of the contract are

\footnotetext{
${ }^{2}$ The guidelines assist firms in carrying out such an examination.
} 
likely to outweigh the exclusionary effects.

The traditional argument regarding ED considers foreclosure as the main anti-competitive effect of such vertical restraint, when it allows a dominant firm to deter an efficient entry (Marvel, 1982;Ater, 2010; Nurski and Verboven, 2011; Hiller, 2012). However, this argument is challenged by the potential efficiency gains, as ED may be a relevant solution to upstream and downstream free-riding problems and opportunistic behaviours (Besanko and Perry, 1993;Heide et al., 1998; Asker, 2004 and 2005; Sass, 2005; Chia-Wen, 2013).

Despite an extensive analysis of such exclusionary contracts in the theoretical field, the empirical literature on ED is limited.

As emphasised by Lafontaine and Slade (2008), most studies focus on a single industry. Examples include beer retailing (Slade, 2000 and 2011; Asker, 2004 and 2005; Sass, 2005; Klick and Wright, 2008; Wen 2013), car market (Brenkers and Verboven, 2006; Nurski and Verboven, 2011),video rental industry(Mortimer, 2008), hamburger chain market (Ater, 2010), and live music industry (Hiller, 2012).This body of literature investigates the outcomes of the exclusionary clauses with respect to prices(Slade, 2000; Sass, 2005), costs (Asker, 2004; Brenkers and Verboven, 2006), profits (Mortimer,2008), market-shares (Nurski and Verboven, 2011; Wen 2013), and sales and consumption (Sass, 2005; Klick and Wright, 2008; Ater, 2010). These papers use various econometric methods including cross-sectional data (e.g., Sass, 2005), panel data (e.g., Slade, 2000; Mortimer, 2008; Hiller, 2012), reduced form models (e.g., Wen 2013) or structural models (e.g., Asker, 2004; Brenkers and Verboven, 2006).

However, there has been little focus to date on the motivations for ED contracts.

The work of Heide et al. (1998) provides some insight into the rationales of ED. Studying the industrial machinery-equipment, electronics and electric equipment sectors, the authors use primary data to estimate a binomial logit model regarding the choice to include an exclusionary clause in the contract. The paper focuses on the determinants of $E$ rather than on the impact of such agreements. The ex ante assessments by the managers are taken into account as explanatory variables. These assessments concern the free-riding on manufacturer services, the transaction costs, the cost imposed on the customers due to the exclusionary clause, the manufacturer differentiation, and the likelihood of competitive entry. The authors find evidence that the manufacturers who care more about their promotional efforts, training, or general support from distributors are more likely to use ED clauses.

This key empirical result is consistent with the efficiency theories of ED. More particularly, Segal and Whinston (2000b) emphasise the impact of the nature of the investments made in the vertical relationships, thus distinguishing several categories of investments with varied influences regarding 
the exclusionary contracts.

Our paper is set in the research field initiated by Heide et al. (1998) and takes into account the theoretical developments since this initial article. While most of the evidence concerns the consequences of ED, we study the empirical rationales of this vertical restraint.

More precisely, this paper reviews the recent development of the theoretical literature that provides explanations of the strategic, anti-competitive motives of ED and the pro-competitive motives of ED in promoting efficient enhancing investment, following the typology of Segal and Whinston (2000b). In doing so, we identify the industrial determinants that may affect the choice for ED agreements and derive testable hypotheses from the theoretical framework. These hypotheses are then submitted to French primary data regarding a wide range of sectors. Our empirical results provide insights into the anti-trust regulation of ED contracts in the European context.

In contrast with the existing empirical literature, this paper addresses several sectors and several types of distribution networks, thus allowing us to compare the market structures that affect directly the motivations for ED. In addition, taking into account the potential endogeneity bias, we control for the influence of the presence of other vertical restraints in the contract - exclusive territories and tying - on the choice to use ED. This is specific to our study as is the control for the potential impact of the geographical location of the suppliers.

This paper proceeds as follows. Section 2 discusses the theoretical background and derives the testable hypotheses. Section 3 provides specifications regarding the French distribution system, the sample and the study variables. Section 4 contains the estimations, and concluding comments are presented in section 5 . 


\section{Theoretical Motivations and Hypotheses}

\subsection{Likelihood of exclusive dealing and anti-competitive motives}

\section{Background}

The rationales of ED have been extensively discussed in the theoretical literature. The Chicago School critique, led by Bork (1978) and Posner (1976), notes that the motive for an exclusive contract is mainly because of efficiency. To induce downstream buyers to sign ED contracts, the upstream incumbent firm must compensate the downstream buyers with at least the same rent that entrant can offer. That is, if the entrant were more efficient, the incumbent would not find it profitable to pay buyers not to trade with the entrant. As a result, if the incumbent succeeds in concluding an ED contract with buyers, it is basically because the incumbent is more efficient.

The Chicago School critique, however, is being challenged. Over the last two decades, increasing attention has been paid to the strategic motives of ED. Although it is widely accepted that ED may have anti-competitive effects, the existing literature provides different rationales under various economic environments. Rasmusen et al. (1991) and Segal and Whinston (2000a) argue that if the entrant firm has to trade with a sufficient number of buyers to achieve scale economy, the incumbent monopolist may opt to use exclusive contracts to deter efficient entry. The intuition of such "naked exclusion" is mainly due to contract externality: if the incumbent has buyers to sign the exclusive contract, the purchase of remaining buyers may not be sufficient to cover the minimum efficient scale of the entrant, and hence, entry will not occur. To this extent, the signed buyers exert a negative externality on other buyers, thus facilitating the incumbent to use a divide-and-conquer strategy to deter efficient entry.

Contract externality is also exploited in Innes and Sexton (1994), where the buyer has the choice to sign a contract and obtain vertical profit with the entry; in Berheim and Whinston (1998), where buyers are independent in different markets and the entrant is viable only if it serves in all the markets; and in Karlinger and Motta (2013), where a product has value only if enough buyers purchase.

Another stream of literature, pioneered by Aghion and Bolton (1987), investigates "partial E". In their framework, the buyer is allowed to breach the exclusive contract and pay damage compensation to the incumbent. In this way, the incumbent can extract some of the surplus created by the efficient entrant by accommodating entry. Similar results are derived by Spier and Whinston (1995), who generalise Aghion and Bolton's model in the context of a renegotiated contract.

The literature discussed above provides useful insights on the rationales of ED. However, these 
papers generally assume that the buyers at the downstream level are either final consumers or independent retailers and that the upstream market contains only an incumbent and a potential entrant, whereas in the real world economy, both the upstream and downstream competition matter in the designing of vertical contracts. A volume of recent literature focuses on these aspects.

\section{Upstream competition}

A few papers investigate the effect of upstream competition on the possibility of signing an exclusive contract. In a framework where the incumbent seller can merge with the potential entrant, Fumagalli et al. (2009) suggest that if the buyer expects weak competition from the entrant, he will be willing to accept exclusivity behind a small compensation, and therefore, ED may occur. In a setting where the incumbent faces multiple potential entrants, Kitamura (2010) argues that the anticompetitive ED is more likely to be observed in industries with few alternative factor inputs, products and technologies.

Based on these results, in which strategic ED is more likely to occur when the upstream competition is weak, we derive the following testable hypothesis:

\section{$H 1$ - The more concentrated the upstream market, the more likely it is that the upstream incumbents sign ED contracts for anti-competitive purposes.}

\section{Downstream competition}

With respect to downstream competition, current analyses reach different conclusions. Fumagalli and Motta distinguish two channels that intensify the downstream competition: the number of downstream firms and the degree of substitution of the final products. In Fumagalli and Motta (2006), exclusion is less likely to occur in case of fierce Bertrand-like downstream competition. Likewise, Fumagalli and Motta (2008) show that the larger number of downstream buyers, the more difficult it is for them to coordinate, and hence, the easier it is for the upstream incumbent to exploit contract externality and foreclose the efficient entrant.

In this framework, and considering the number of firms as a measure of the degree of downstream competition, we formulate the following hypothesis:

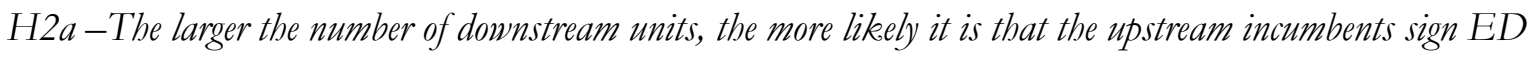
contracts for anti-competitive purposes.
} 
With respect to product substitution, Fumagalli and Motta (2008) demonstrate that if the downstream competition stems from the substitution of products, a buyer can obtain greater profit by switching to an efficient entrant who offers a competitive wholesale price. Hence, the incumbent cannot profitably foreclose the entrant. As a result, the intense downstream competition based on the substitution of products makes strategic ED less likely. This argument is, however, challenged by the recent analysis that argues that Fumagalli and Motta's (2008) framework is based on a strong assumption that the downstream buyers can be inactive under fierce Bertrand-like competition. Simpson and Wickelgren (2007) find that if buyers are allowed to break the contract and pay expected damage to the incumbent (as in the Aghion and Bolton framework), ED is more likely to occur if downstream competition becomes intense. The reason for this is that the downstream buyers, although in competition, always remain active in the market. When entry occurs, the intense inter- and intra-brand competition eliminates almost all the vertical profit. As a result, it is easier for the incumbent to sign an exclusive contract with the buyer to foreclose the entrant and obtain monopoly profits of the industry. Similar results are found in Abito and Wright (2008), Wright (2009) and Gratz and Reisinger (2013).

With respect to the degree of substitution, we follow the argument of Simpson and Wickelgren(2007), Abito and Wright (2008), Wright (2009) and Gratz and Reisinger (2013) to derive the following hypothesis:

\section{H2b-The more substitutable the final products are, the more likely it is that the upstream incumbents sign ED contracts for anti-competitive purposes.}

The literature and the embodied rationales for strategic ED contracts can be summarised as follows (Table 1): 
Table 1 -Anti-competitive motives for exclusive dealing

\begin{tabular}{|c|c|c|c|}
\hline Industry Structure & References & Results & Basic Rationales \\
\hline \multirow{2}{*}{$\begin{array}{l}\text { Basic structure: } \\
\text { Upstream } \\
\text { incumbent } \\
\text { and entrant } \\
\text { competing for } \\
\text { independent } \\
\text { downstream buyers }\end{array}$} & $\begin{array}{l}\text { Rasmusen et al. (1991), } \\
\text { Segal and Whinston } \\
\text { (2002a), Innes and } \\
\text { Sexton (1994), Berheim } \\
\text { and Whinston (1998), } \\
\text { Karlinger and Motta } \\
\text { (2013) }\end{array}$ & $\begin{array}{l}\text { Naked ED: incumbent can } \\
\text { block efficient entrant using } \\
\text { ED contract. }\end{array}$ & $\begin{array}{l}\text { If buyers cannot coordinate and entry requires } \\
\text { enough buyers to purchase, there is contract } \\
\text { externality of ED that prevents entry. }\end{array}$ \\
\hline & $\begin{array}{l}\text { Agion and Bolton (1987), } \\
\text { Spier and Whinston } \\
(1995)\end{array}$ & $\begin{array}{l}\text { Partial ED: incumbent signs } \\
\text { ED and entry occurs. }\end{array}$ & $\begin{array}{l}\text { Incumbent can extract some rent from efficient } \\
\text { entrant through the contract-breach } \\
\text { compensation stipulated in the ED contract. }\end{array}$ \\
\hline $\begin{array}{l}\text { Upstream } \\
\text { competition } \\
\text { or coordination }\end{array}$ & $\begin{array}{l}\text { Fumagalli et al.(2009) } \\
\text { Kiamura (2010) }\end{array}$ & $\begin{array}{l}\text { H1: The more concentrated } \\
\text { the upstream market, the } \\
\text { more likely that the } \\
\text { upstream incumbents sign } \\
\text { ED contracts. }\end{array}$ & $\begin{array}{l}\text { Intensive upstream competition gives buyers } \\
\text { more outside options, making it difficult to } \\
\text { accept. }\end{array}$ \\
\hline \multirow{2}{*}{$\begin{array}{l}\text { Downstream } \\
\text { competition } \\
\text { stemming from } \\
\text { number of firms } \\
\text { and product } \\
\text { substitution }\end{array}$} & $\begin{array}{l}\text { Fumagalli and Motta } \\
(2006) \text {, Fumagalli and } \\
\text { Motta (2008) }\end{array}$ & $\begin{array}{l}\text { H2a: The larger the number } \\
\text { of downstream units, the } \\
\text { more likely that the } \\
\text { upstream incumbents sign } \\
\text { ED contracts. }\end{array}$ & $\begin{array}{l}\text { A large number of downstream buyers make } \\
\text { it difficult for them to coordinate; hence, } \\
\text { ED is easier to achieve. } \\
\text { Harsh downstream competition. }\end{array}$ \\
\hline & $\begin{array}{l}\text { Simpson and Wickelgren } \\
\text { (2007), Abito and Wright } \\
\text { (2008), Wright (2008), } \\
\text { Gratz and Reisinger } \\
\text { (2013) }\end{array}$ & $\begin{array}{l}\text { H2b: The } \\
\text { substitutable the final } \\
\text { products, the more likely } \\
\text { that the upstream } \\
\text { incumbents sign ED } \\
\text { contracts. }\end{array}$ & $\begin{array}{l}\text { The intense inter- and intra-brand competition } \\
\text { reduces the potential rent that entrants can offer } \\
\text { to buyers, and hence, it is easier to accept ED. }\end{array}$ \\
\hline
\end{tabular}

\subsection{Exclusive dealing and investment incentives}

\section{Background}

The literature highlighting the efficiency aspects of ED mainly focuses on the strong link between exclusionary provisions and the beneficiary's investment incentive. The conventional perspective in this field recognises that exclusive contracts can be used to protect the investment of a party in the vertical relationship and that, as a result, they can foster such an investment (see, for example, Marvel 1982, Fransco 1991, Mastern and Snyder 1993 for informal discussion). This notion has been exploited in Besanko and Perry (1993), who argue that an ED contract can be used to prevent the free-ride of the competitors on non-relationship-specific investments. In fact, under 
$\mathrm{ED}$, an investment becomes specific to the vertical relationship, and hence, it eliminates the interbrand externality among retailers.

Segal and Whinston (2000b) analyse the relationship between investment and ED in a more general framework. Unlike the conventional perspective, these authors argue that whether ED fosters investment depends on who invests in the vertical relationship and on the nature of the investment. In particular, if the investment is complementary, in that it increases the value of trade between the entrant and buyers, then ED fosters the investment of the incumbent seller while reducing the investment incentive of downstream buyers. On the other hand, if the investment is substitutable, in that it reduces the trade value for the entrant and the buyers, ED reduces the incumbent seller's investment but increases the investment of downstream buyers. As the investment only affects the internal trade value of contractually locking parties, ED is irrelevant for these parties' investment decisions.

Following the work of Segal and Whinston (2000b), a number of papers challenge the irrelevance result of ED. Che and Sakovics (2004) argue that the irrelevance result does not hold in a dynamic model in which the timing of investments and bargaining is endogenous. Meza and Selvaggi (2007) suggest that ED can increase the recipient's bargaining power, thus enabling such power to extract an increased share of the surplus created by its investment. However, de Fontenay et al. (2010) generalise the model of Segal and Whinston and find that their irrelevance results still hold in their setting. Fumagalli et al. (2012) argue that because ED affects the investment incentive depends on the investment cost, the irrelevance result holds if the investment cost is small. However, ED promotes investment and forecloses entry if the investment cost is large.

\section{Upstream investment}

Thus, the literature shows that there is no general conclusion on the linkage between ED and investment, in particular, for the internal, relation-specific investment and that the work of Segal and Whinston (2000b) remains central. For this reason, we base our hypotheses on this key reference with the aim being to study whether the theory still holds in the real world economy. Accordingly, we derive the following hypotheses regarding the upstream investments:

H3a -In the presence of upstream complementary investments, it is more likely that the upstream incumbents sign ED contracts for efficiency purpose.

$H 3 b$-In the presence of upstream substitutable investments, it is less likely that the upstream incumbents sign ED contracts. 


\section{Downstream investment}

In addition, the following testable propositions can be considered regarding the downstream investments:

$\mathrm{H} 4 \mathrm{a}$ - In the presence of downstream complementary investments, it is less likely that the upstream incumbents sign ED contracts.

$H 4 b$ - In the presence of downstream substitutable investments, it is more likely that the upstream incumbents sign ED contracts for anti-competitive purposes.

The economic rationales of pro-competitive efficient ED are summarised in Table 2:

Table 2 - ED and investment incentives

\begin{tabular}{|c|c|c|c|c|}
\hline \multirow{2}{*}{$\begin{array}{c}\text { Reference } \\
\text { Segal and Whinston (2000b) }\end{array}$} & \multicolumn{2}{|c|}{ Upstream incumbent invests } & \multicolumn{2}{|c|}{ Downstream retailers invests } \\
\hline & Hypotheses & Basic Rationales & Hypotheses & Basic Rationales \\
\hline $\begin{array}{l}\text { Complementary investments: } \\
\text { benefit the trade between } \\
\text { competitors and retailers }\end{array}$ & $\begin{array}{l}\text { H3a: } \\
\text { Efficient ED is } \\
\text { more likely. }\end{array}$ & $\begin{array}{l}\text { ED can protect } \\
\text { the investment of } \\
\text { incumbent from } \\
\text { the free-ride of } \\
\text { competitors. }\end{array}$ & $\begin{array}{l}\text { H4a: } \\
\text { Anti-competitive } \\
\text { ED is less likely. }\end{array}$ & $\begin{array}{l}\text { ED reduces the incentive of } \\
\text { retailer to invest in favour } \\
\text { of the competing sellers } \\
\text { and, hence, can help the } \\
\text { incumbent to dampen the } \\
\text { position of competitors. }\end{array}$ \\
\hline $\begin{array}{l}\text { Substitutable investments: } \\
\text { reduce the trade between } \\
\text { competitors and retailers }\end{array}$ & $\begin{array}{l}\text { H3b: } \\
\text { ED is less likely. }\end{array}$ & $\begin{array}{l}\text { Incumbent has } \\
\text { incentive to invest } \\
\text { and dampen the } \\
\text { position of its } \\
\text { competitors. ED is } \\
\text { of no use. }\end{array}$ & $\begin{array}{l}\text { H4b: } \\
\text { Anti-competitive } \\
\text { ED is more likely. }\end{array}$ & $\begin{array}{l}\text { ED gives the retailer more } \\
\text { incentive to invest as it } \\
\text { dampens the position of } \\
\text { competitors to the benefit } \\
\text { of trading with the } \\
\text { incumbent. }\end{array}$ \\
\hline
\end{tabular}




\section{Empirical Specifications}

\subsection{The French system}

The French distribution system is characterised by a diversity of organisational forms. The two main organisational forms are company-owned chains, where the outlets belong to the upstream firm or to one of its subsidiaries, and franchised networks, where the upstream firm transmits its business format and monitors the independent downstream units to maintain the brand's reputation.

Other types of governance forms in the French system include (i) retailer cooperatives, where the upstream unit in charge of the promotion of the common brand belongs to the retailers; (ii) brand licensed networks, which are similar to business format franchises, but less constraining for the downstream units; (iii) concession networks, which are similar to traditional franchises; and (iv) commission-based affiliations (CBA), which are similar to business-format franchises but more constraining as the stock shares at the downstream level are owned by the upstream firm.

Each of these networks may choose to include an ED clause in the vertical contracts. Notably, as mentioned by Lafontaine and Slade (2013), the European legal environment provides franchisors great flexibility to impose or rely on ED.

\subsection{The sample}

Between 2006 and 2008, the French National Institute of Statistics and Economic Studies (INSEE) conducted several surveys to collect information regarding the distribution networks over seven units. The networks, and more precisely, the upstream units (i.e., the head-ends), were surveyed through a questionnaire distributed by postal mailing.

The original dataset used in this study compiles primary data produced by the INSEE. This dataset is exhaustive and covers all retail sectors. As a result of matching and of the retropolation of the data, our cross-sectional dataset refers to the year 2007.

The sample consists of 504 networks of independent retailers using the same brand name.

As presented in Table 3, seven types of networks are distinguished in the sample. More than half of the networks $(53 \%)$ use the same type of vertical contract with all of their outlets. The other networks mix several types of relationships. In the sample, each network is allocated a type according to the share of the network turnover achieved by each type of outlet. The algorithm successively tests the condition in the second column of Table 3 and stops when a condition is deemed true. 
Three types of franchised networks are distinguished to consider the presence of integrated retail outlets that are owned and directly operated by the upstream firm for each franchised network. These three categories of franchised networks include franchised and slightly mixed with owned retail units, franchised and highly mixed with owned retail units, and predominantly integrated network.

Table 3: Seven types of distribution networks (INSEE definition)

\begin{tabular}{l|l}
\hline \multicolumn{1}{c|}{ Network type } & \multicolumn{1}{c}{ Condition } \\
\hline $\begin{array}{l}\text { Franchised slightly mixed } \\
\text { Franchised highly mixed }\end{array}$ & $\begin{array}{l}\text { More than } 50 \% \text { of the network turnover (NT) is achieved by franchised units } \\
\text { Predominantly integrated } \\
\text { Brand License }\end{array}$ \\
$\begin{array}{l}\text { Commission-based affiliation } 20 \% \text { and } 50 \% \text { of the NTis achieved by franchised units } \\
\text { Concession }\end{array}$ & $\begin{array}{l}\text { More than } 50 \% \text { of the NTis achieved by company-owned outlets } \\
\text { Cooperative }\end{array}$ \\
& $\begin{array}{l}\text { More than } 50 \% \text { of the NTis achieved by outlets with a brand license contract } \\
\text { More than } 50 \% \text { of the NTis achieved by outlets with a concession contract } \\
\text { cooperative }\end{array}$ \\
\hline
\end{tabular}

The sample covers a wide range of activities grouped into 15 sectors according to the INSEE classification. The sector-based distribution of the sample networks is presented in Table 4. This table shows that the two main sectors are «Clothing retail» $(20.24 \%$ of sample networks) and « Home equipment» (19.05\% of sample networks).

Table 4: Sector-based distribution of the sample networks

\begin{tabular}{l|ll}
\hline & $\begin{array}{l}\text { Number of } \\
\text { networks }\end{array}$ & in sample \\
\hline Maintenance and repair of motor vehicles and automotive equipment trade & 16 & 3.17 \\
Retailing predominantly in food supermarkets & 5 & 0.99 \\
Retailing general supply or frozen products in small stores & 9 & 1.79 \\
Equipment for individuals & 51 & 10.12 \\
Culture-leisure-sports & 46 & 9.13 \\
Home equipment & 96 & 19.05 \\
Development of housing & 46 & 9.13 \\
Non-food, non-specialised retail stores & 5 & 0.99 \\
Craft businesses & 15 & 3.63 \\
Trade and repair of motorcycles & 5 & 0.99 \\
Retail sale of food in specialised stores & 29 & 5.75 \\
Retail sale of medical and orthopaedic devices & 11 & 2.18 \\
Other retail stores specialising in non-food items & 45 & 8.93 \\
Clothing retail & 102 & 20.24 \\
Retail shoes & 23 & 4.56 \\
\hline
\end{tabular}




\subsection{Distribution of the ED clause}

Tables 3 to 5 present the distribution of the ED clause in the sample networks (Table 5), within the 15 sectors (Table 6), and within the network types (Table 7). The precise question in the survey questionnaire reflects the possible duty of the independent retailers in the network. This question is as follows: "Do you impose on your retailers an ED with the network central purchasing unit or with referenced suppliers?" The possible responses are "yes" or "no".

As highlighted in Tables 3 to 5, the distribution of the ED clause is quite balanced in the sample (46.43 of the sample networks use ED), within the retail sectors, and within the network types. However, its prevalence in the sectors "Retail sale of food in specialised stores" (69\%) and "Clothing retail" (67\%) with respect to the organisational forms "Predominantly integrated" (68 \%) and "Commission-based Affiliation" (70.6\%) are evident.

Table 5: Distribution of the ED clause in the sample networks

\begin{tabular}{l|ll}
\hline & Freq & $\%$ \\
\hline No- ED & 270 & 53.57 \\
ED & 234 & 46.43 \\
Total & 504 & 100 \\
\hline
\end{tabular}

Table 6: Distribution of the ED clause within the 15 sectors

\begin{tabular}{l|lll}
\hline \multicolumn{1}{c|}{ Sectors } & No-ED & ED & Total \\
\hline Maintenance and repair of motor vehicles and automotive equipment trade & 11 & 5 & 16 \\
Retailing predominantly in food supermarkets & 4 & 1 & 5 \\
Retailing general supply or frozen products in small stores & 3 & 6 & 9 \\
Equipment for individuals & 30 & 21 & 51 \\
Culture-leisure-sports & 31 & 15 & 46 \\
Home equipment & 49 & 47 & 96 \\
Development of housing & 36 & 10 & 46 \\
Non-food, non-specialised retail stores & 5 & 0 & 5 \\
Craft businesses & 8 & 7 & 15 \\
Trade and repair of motorcycles & 4 & 1 & 5 \\
Retail sale of food in specialised stores & 9 & 20 & 29 \\
Retail sale of medical and orthopaedic devices & 7 & 4 & 11 \\
Other retail stores specialising in non-food items & 28 & 17 & 45 \\
Clothing retail & 34 & 68 & 102 \\
Retail shoes & 11 & 12 & 23 \\
Total & 270 & 234 & 504 \\
\hline
\end{tabular}


Table 7: Distribution of the ED clause within the network types

\begin{tabular}{l|ccc}
\hline \multicolumn{1}{c|}{ Network type } & No-ED & ED & Total \\
\hline Brand license & 31 & 11 & 42 \\
Concession & 23 & 16 & 39 \\
Franchised and slightly mixed & 71 & 47 & 118 \\
Franchised and highly mixed & 21 & 27 & 48 \\
Predominantly integrated & 47 & 102 & 149 \\
Cooperative & 72 & 19 & 91 \\
Commission-based affiliation & 5 & 12 & 17 \\
Total & 270 & 234 & 504 \\
\hline
\end{tabular}

\subsection{The study variables}

The study variables are presented in Table 6. The dependent variable is a dummy denoting the presence of an ED clause in the vertical contract. The core explanatory variables derived from the analytical framework relate to the upstream and downstream competition levels and to the upstream and downstream investments. In addition, we add several control variables.

\section{Upstream competition}

The market concentration is measured in four ways. First, we use the market share of the network, defined as the network turnover divided by the sector turnover. Each of the 15 sectors in the dataset relates to a market where the upstream firms compete. Second, we calculate the HerfindablHirschman index (HHI) for these markets. Third, we take into account the interaction between the market share and the Herfindahl-Hirschman index with a multiplicative variable (Market share * $H H I)$. Finally, we consider the size of the market segment, i.e., the number of networks for each segment. Again, we use the INSEE nomenclature for this complementary and finer classification of activities and distinguish 25 segments in the sample.

\section{Downstream competition}

The features of the downstream competition are related to the number of downstream units and to the type of product, more or less substitutable.

We measure the number of downstream units for each network (size of the network) and for each market (size of the market, which is 15 markets). A multiplicative variable cannot be introduced due to multicolinearity problems. 
In addition, two types of products are distinguished: substitutable and non-substitutable. Substitutable products are characterised by automatic, high frequency purchases such that no substitutable products involve well-thought-out purchasing decisions or higher research costs for consumers. Such a proxy variable was previously used by Brickley (1999). Table 8 presents the sector distribution used to construct the dummy variable: substitutable or non-substitutable.

Table 8: Construction of the dummy variable: substitute

\begin{tabular}{l|l}
\hline \multicolumn{1}{c|}{ Sector } & Type of product \\
\hline Maintenance and repair of motor vehicles and sale of motor vehicle parts and accessories & non-substitutable \\
Large-scale food retailing stores & substitutable \\
Retailing general supply or frozen products in small stores & substitutable \\
Personal and household goods (except clothes and shoes) & non-substitutable \\
Cultural and recreation goods stores & non-substitutable \\
Home equipment stores & non-substitutable \\
Development of housing & substitutable \\
Retail non-food non-specialised stores & substitutable \\
Craft businesses & non-substitutable \\
Trade and repair of motorcycles & non-substitutable \\
Retail sale of food in specialised stores & non-substitutable \\
Retail sale of medical and orthopaedic & non-substitutable \\
Other retail stores specialising in non-food & substitutable \\
Clothes stores & substitutable \\
Shoe stores & substitutable \\
\hline
\end{tabular}

\section{Upstream investment}

With respect to investments that benefit the trade between the upstream competitors and the downstream units, upstream complementary investments are closely related to the initial training provided by the upstream unit to the downstream firms and to the transmission of expertise by the upstream structure to the downstream units.

In contrast, upstream substitutable investments have a negative impact on the trade between the upstream competitors and the downstream units. We construct an index of the upstream substitutable investment with seven variables related to the functions possibly performed by the upstream firm in the vertical relationship: the definition of the assortment of the stores, logistics functions (storage, warehousing, delivery to retail outlets), the definition of the services provided to the consumers, the tracking of sales, the diffusion in the network of the performances regarding the outlets sales, invitations to be part of the strategic commissions of the network (marketing, communication, etc.), the help to transmit the outlet. In the dataset provided by the INSEE, each of these variables is taken into account as a dummy. Our index is defined as the sum of these seven dummy variables. The higher the index is, the more substitutable the upstream investment. 


\section{Downstream investment}

The downstream complementary investment refers to the efforts exerted or investments made by the retailers in favour of the trade with the upstream competitors. Such investment is measured as the services provided by the network outlets to the final consumers, such as advice, or by demonstration sessions.

With respect to the downstream substitutable investments, which impede trade with the upstream competitors, we use an index constructed with four dummy variables regarding the investment of the downstream units in the vertical relationships: the payment of an entrance fee or the subscription of shares, the payment of fixed contributions, the payment of royalties related to the turnover of the outlet, and the financial participation in advertising campaigns.

\section{Control variables}

We add ten control variables. First, considering that the network experience may influence the contractual design, we control for the impact of the age of the network and the impact of an upstream unit of another branded network on the choice to use ED.

Second, because it is relevant to study each contractual provision as part of a whole, we control for the influence of other vertical restraints included in the contract on the decision to use ED. As mentioned by Slade (2008), vertical restraints are often analysed in isolation, whereas theory demonstrates that they can be substitutes or complements. Aiming at controlling for such relationships, we consider the presence of an exclusive territory clause granted to the downstream units, as well as the presence of tying imposed on the downstream units. However, this issue may raise endogeneity problems, which are taken into account.

Third, we control for the influence of the type of network, taking into account the distinction among the seven distribution networks in the French system (see Table 1). The aim is to study the potential impact of the organisational form on the contractual design. For example, as argued by Innes and Sexton (1994), if the downstream buyers can vertically integrate with the upstream entrant, ED is generally efficient as it deters inefficient entry. Hence, the organisational form may also be an important factor affecting ED. Finally, we add dummies regarding the geographical location of the upstream structure, which is new in the empirical literature on ED. This original perspective enables us to take into account three main types of structural determinants that may affect the individual choice to include ED in distribution contracts: the geographical dimension, the industrial features that comprise the market structure, and the network organisational form. Five locations are considered: the area of the capital city, the north-eastern part of the country, the north-western part of the country, the south-eastern part of the country, and the south-western part of the country. 
Table 9. Summary statistics (504 distribution networks)

\begin{tabular}{|c|c|c|c|c|c|c|}
\hline Variables & Definition & Mean & Std. Dev. & Min & $\operatorname{Max}$ & Type \\
\hline \multicolumn{7}{|l|}{ Dependent variable } \\
\hline ED & Exclusive dealing clause included in the vertical contract & .4642857 & .4992184 & 0 & 1 & Dummy variable \\
\hline \multicolumn{7}{|c|}{ Explanatory variables derived from the bypotheses } \\
\hline MARKETSHARE & Market share of the network (network turnover/market turnover) & .0297619 & .0698682 & .0000693 & 3.6048392 & Quantitative variable \\
\hline $\mathrm{HHI}$ & Herfindahl-Hirschmann index & 9.615324 & 8.760991 & 3.146751 & 144.62323 & Quantitative variable \\
\hline MARKSHARHHI & Market share * HHI (multiplicative) & .0029568 & .004568 & .000017 & .0312769 & Quantitative variable \\
\hline SIZESEGMENT & Size of market segment (number of networks) & 39.19841 & 35.14079 & 1 & 102 & Quantitative variable \\
\hline SIZENET & Size of network (number of downstream outlets) & 180.004 & 488.4781 & 7 & 7770 & Quantitative variable \\
\hline SIZEMARKET & Size of market (number of downstream outlets) & 9689.278 & 5098.248 & 227 & 16402 & Quantitative variable \\
\hline SUBSTITUTE & Type of product: substitutable versus non-substitutable & .5337302 & .4993566 & 0 & 1 & Dummy variable \\
\hline INITRAIN & Initial training provided by upstream to downstream units & .7777778 & .4161528 & 0 & 1 & Dummy variable \\
\hline TRANSF & Transmission of expertise by upstream to downstream units & .8214286 & .3833736 & 0 & 1 & Dummy variable \\
\hline SERVICE & Services provided by downstream units to final consumers & .4801587 & .5001025 & 0 & 1 & Dummy variable \\
\hline UPSUBSTI & Upstream substitutable investment & 8.234127 & 2.823634 & 0 & 13 & Index summing 7 dummies \\
\hline DOWNSUBSTI & Downstream substitutable investment & 2.236111 & 1.221822 & 0 & 4 & Index summing 4 dummies \\
\hline \multicolumn{7}{|l|}{ Control variables } \\
\hline AGE & Age of network & 21.31092 & 19.81727 & 0 & 184 & Quantitative variable \\
\hline OTHERNET & Operation of upstream unit of another branded network & 1.333333 & .9437458 & 0 & 2 & Dummy variable \\
\hline EXCLUTERRI & Exclusive territory granted to downstream unit & .7142857 & .4522028 & 0 & 1 & \multirow{2}{*}{$\begin{array}{l}\text { Dummy variables for the } \\
\text { impact of another restraint }\end{array}$} \\
\hline TYING & Tying imposed on downstream unit & .6468254 & .4784313 & 0 & 1 & \\
\hline TYPENET & Type of network (7 organisational forms distinguished) & 3.119048 & 1.614335 & 0 & 6 & Qualitative variable \\
\hline CAPITALCITY & Area of capital city & .4146825 & .4931566 & 0 & 1 & \multirow{5}{*}{$\begin{array}{l}\text { Dummy variables for the } \\
\text { geographical location of the } \\
\text { upstream unit }\end{array}$} \\
\hline NORTHEAST & Northeast area of country & .1190476 & .3241663 & 0 & 1 & \\
\hline NORTHWEST & Northwest area of country & .156746 & .3639224 & 0 & 1 & \\
\hline SOUTHEAST & Southeast area of country & .1845238 & .3882962 & 0 & 1 & \\
\hline SOUTHWEST & Southwest area of country & .125 & .3310475 & 0 & 1 & \\
\hline
\end{tabular}

Dummy variables (0/1): $0=$ no; $1=$ yes

Dummy variables $(0-2)$ used to construct UPSUBSTI: $0=$ no; $1=$ yes partially; $2=$ yes completely

Dummy variable (0-2) OTHERNET: $0=$ yes; $2=$ no

Dummy variables (0/1) SUBSTITUTE: $0=$ substitutable; $1=$ non-substitutable 


\section{Empirical Determinants of Exclusive Dealing}

\subsection{Specification tests}

The Breusch-Pagan test is performed and allows concluding for heteroscedasticity. Accordingly, the standard errors are corrected using White's method.

The low values of the variance inflation factors suggest that there is no multicolinearity problem (see Appendix 1), while the Pearson chi-square tests, which are applied to determine whether a relationship exists between the categorical variables, highlight a dependence between OTHERNET and TYING (critical probability ${ }^{3}: \operatorname{Pr}=0.035$ ), between OTHERNET and TYPENET (critical probability: $\operatorname{Pr}=0.000$ ), between EXCLUTERRI and TYING (critical probability: $\operatorname{Pr}=0.007$ ), between EXCLUTERRI and TYPENET (critical probability: $\operatorname{Pr}=$ 0.020), between TYING and TYPENET (critical probability: $\operatorname{Pr}=0.000$ ). Accordingly, we provide estimates using a step-by-step econometric approach and introduce these regressors gradually (Table 11). In addition, we introduce the estimation of models including these variables simultaneously (Table 10).

\subsection{Estimation results}

Table 10. Probit estimates for exclusive dealing

\begin{tabular}{|c|c|c|c|c|c|}
\hline & $(1)$ & $(2)$ & (3) & (4) & $(5)$ \\
\hline AGE & $\begin{array}{l}-0.00112 \\
(0.00338)\end{array}$ & $\begin{array}{l}-0.00190 \\
(0.00344)\end{array}$ & $\begin{array}{l}-0.00167 \\
(0.00356)\end{array}$ & $\begin{array}{l}-0.00226 \\
(0.00338)\end{array}$ & $\begin{array}{l}-0.00239 \\
(0.00342)\end{array}$ \\
\hline OTHERNET & $\begin{array}{c}0.132^{*} \\
(0.0660)\end{array}$ & $\begin{array}{c}0.144^{*} \\
(0.0667)\end{array}$ & $\begin{array}{c}0.147^{*} \\
(0.0682)\end{array}$ & $\begin{array}{c}0.229^{* *} \\
(0.0744)\end{array}$ & $\begin{array}{c}0.224^{* *} \\
(0.0751)\end{array}$ \\
\hline EXCLUTERRI & $\begin{array}{c}0.510^{* * *} \\
(0.137)\end{array}$ & $\begin{array}{c}0.513^{* * *} \\
(0.139)\end{array}$ & $\begin{array}{c}0.560^{* * * *} \\
(0.142)\end{array}$ & $\begin{array}{l}0.373^{*} \\
(0.156)\end{array}$ & $\begin{array}{l}0.404^{* *} \\
(0.155)\end{array}$ \\
\hline TYING & $\begin{array}{c}0.784^{* * *} \\
(0.130)\end{array}$ & $\begin{array}{c}0.799^{* * *} \\
(0.131)\end{array}$ & $\begin{array}{c}0.784^{* * *} \\
(0.134)\end{array}$ & $\begin{array}{c}0.562^{* * *} \\
(0.147)\end{array}$ & $\begin{array}{c}0.566^{* * *} \\
(0.150)\end{array}$ \\
\hline TYPENET & $\begin{array}{c}0.0735 \\
(0.0385)\end{array}$ & $\begin{array}{c}0.0699 \\
(0.0386)\end{array}$ & $\begin{array}{c}0.0738 \\
(0.0417)\end{array}$ & $\begin{array}{c}0.0756 \\
(0.0475)\end{array}$ & $\begin{array}{c}0.0826 \\
(0.0474)\end{array}$ \\
\hline CAPITALCITY & $\begin{array}{l}0.292^{*} \\
(0.126)\end{array}$ & $\begin{array}{l}0.273^{*} \\
(0.129)\end{array}$ & $\begin{array}{l}0.332^{*} \\
(0.135)\end{array}$ & $\begin{array}{l}0.407^{* *} \\
(0.148)\end{array}$ & \\
\hline MARKETSHARE & & $\begin{array}{l}-0.266 \\
(1.380)\end{array}$ & $\begin{array}{l}-1.070 \\
(1.379)\end{array}$ & $\begin{array}{l}-0.461 \\
(1.402)\end{array}$ & $\begin{array}{l}-0.119 \\
(1.407)\end{array}$ \\
\hline $\mathrm{HHI}$ & & -0.00683 & 0.0114 & 0.00659 & 0.00557 \\
\hline
\end{tabular}

${ }^{3}$ The null hypothesis $\mathrm{H}_{0}$ is the hypothesis of independence. 


\begin{tabular}{|c|c|c|c|c|c|}
\hline & & $(0.00915)$ & $(0.0125)$ & $(0.0138)$ & $(0.0138)$ \\
\hline MARKSHARHHI & & $\begin{array}{c}21.54 \\
(19.70)\end{array}$ & $\begin{array}{c}35.92 \\
(20.99)\end{array}$ & $\begin{array}{c}31.09 \\
(22.84)\end{array}$ & $\begin{array}{c}25.92 \\
(22.87)\end{array}$ \\
\hline SIZENET & & & $\begin{array}{c}-0.0000986 \\
(0.000157)\end{array}$ & $\begin{array}{c}-0.0000357 \\
(0.000179)\end{array}$ & $\begin{array}{c}-0.0000366 \\
(0.000178)\end{array}$ \\
\hline SIZEMARKET & & & $\begin{array}{l}-0.0000424 \\
(0.0000264)\end{array}$ & $\begin{array}{l}-0.0000436 \\
(0.0000285)\end{array}$ & $\begin{array}{c}-0.0000484 \\
(0.0000288)\end{array}$ \\
\hline SIZESEGMENT & & & $\begin{array}{l}0.0145^{\text {*** }} \\
(0.00353)\end{array}$ & $\begin{array}{l}0.0142^{* * *} \\
(0.00379)\end{array}$ & $\begin{array}{l}0.0153^{* * *} \\
(0.00383)\end{array}$ \\
\hline SUBSTITUTE & & & $\begin{array}{c}0.287 \\
(0.171)\end{array}$ & $\begin{array}{l}0.394^{*} \\
(0.185)\end{array}$ & $\begin{array}{l}0.422^{*} \\
(0.186)\end{array}$ \\
\hline INITRAIN & & & & $\begin{array}{l}0.569^{* *} \\
(0.212)\end{array}$ & $\begin{array}{l}0.563^{* *} \\
(0.216)\end{array}$ \\
\hline TRANSF & & & & $\begin{array}{l}0.716^{* *} \\
(0.245)\end{array}$ & $\begin{array}{l}0.727^{* *} \\
(0.243)\end{array}$ \\
\hline SERVICE & & & & $\begin{array}{c}0.137 \\
(0.142)\end{array}$ & $\begin{array}{c}0.134 \\
(0.142)\end{array}$ \\
\hline UPSUBSTI & & & & $\begin{array}{l}0.126^{* * *} \\
(0.0287)\end{array}$ & $\begin{array}{l}0.126^{* * *} \\
(0.0296)\end{array}$ \\
\hline DOWNSUBSTI & & & & $\begin{array}{l}-0.0996 \\
(0.0619)\end{array}$ & $\begin{array}{c}-0.102 \\
(0.0626)\end{array}$ \\
\hline SOUTHEAST & & & & & $\begin{array}{l}-0.396^{*} \\
(0.192)\end{array}$ \\
\hline SOUTHWEST & & & & & $\begin{array}{l}-0.225 \\
(0.231)\end{array}$ \\
\hline NORTHEAST & & & & & $\begin{array}{l}-0.205 \\
(0.218)\end{array}$ \\
\hline NORTHWEST & & & & & $\begin{array}{c}-0.763^{* * *} \\
(0.212)\end{array}$ \\
\hline _cons & $\begin{array}{c}-1.475^{* * *} \\
(0.220)\end{array}$ & $\begin{array}{c}-1.462^{* * *} \\
(0.251)\end{array}$ & $\begin{array}{c}-2.031^{* * *} \\
(0.357)\end{array}$ & $\begin{array}{c}-3.872^{* * *} \\
(0.467)\end{array}$ & $\begin{array}{c}-3.492^{* * *} \\
(0.487)\end{array}$ \\
\hline Prob> chi2 & 0.0000 & 0.0000 & 0.0000 & 0.0000 & 0.0000 \\
\hline Pseudo $\mathrm{R}^{2} \%$ & 0.1130 & 0.1175 & 0.1531 & 0.2635 & 0.2728 \\
\hline Predicted & 68.28 & 67.23 & 69.12 & $73.95 \%$ & $74.79 \%$ \\
\hline \multicolumn{4}{|c|}{ Area under ROC curve } & 0.8222 & 0.8270 \\
\hline
\end{tabular}

Robust standard errors in brackets ${ }^{*} p<0.05,{ }^{* *} p<0.01,{ }^{* * *} p<0.001$ 
Table 11. Step-by-step probit estimates for exclusive dealing

\begin{tabular}{|c|c|c|c|c|c|}
\hline & (6) & $(7)$ & (8) & (9) & $(10)$ \\
\hline AGE & $\begin{array}{l}-0.00167 \\
(0.00328)\end{array}$ & $\begin{array}{l}-0.00180 \\
(0.00329)\end{array}$ & $\begin{array}{l}-0.00206 \\
(0.00327)\end{array}$ & $\begin{array}{l}-0.00244 \\
(0.00336)\end{array}$ & $\begin{array}{l}-0.00218 \\
(0.00330)\end{array}$ \\
\hline OTHERNET & $\begin{array}{l}0.263^{* * *} \\
(0.0727)\end{array}$ & $\begin{array}{l}0.256^{* * *} \\
(0.0730)\end{array}$ & & & \\
\hline EXCLUTERRI & & $\begin{array}{l}0.371^{*} \\
(0.153)\end{array}$ & $\begin{array}{l}0.392^{* *} \\
(0.151)\end{array}$ & & \\
\hline TYING & & & & $\begin{array}{c}0.628^{* * *} \\
(0.146)\end{array}$ & \\
\hline TYPENET & & & & & $\begin{array}{c}0.0774 \\
(0.0457)\end{array}$ \\
\hline MARKETSHARE & $\begin{array}{c}0.232 \\
(1.424)\end{array}$ & $\begin{array}{c}0.124 \\
(1.427)\end{array}$ & $\begin{array}{c}0.131 \\
(1.459)\end{array}$ & $\begin{array}{c}-0.00398 \\
(1.445)\end{array}$ & $\begin{array}{c}0.266 \\
(1.451)\end{array}$ \\
\hline HHI & $\begin{array}{l}0.00530 \\
(0.0139)\end{array}$ & $\begin{array}{l}0.00823 \\
(0.0143)\end{array}$ & $\begin{array}{l}0.00751 \\
(0.0143)\end{array}$ & $\begin{array}{l}0.00373 \\
(0.0136)\end{array}$ & $\begin{array}{l}0.00222 \\
(0.0138)\end{array}$ \\
\hline MARKSHARHHI & $\begin{array}{l}11.96 \\
(21.58)\end{array}$ & $\begin{array}{c}18.22 \\
(21.62)\end{array}$ & $\begin{array}{c}15.19 \\
(20.70)\end{array}$ & $\begin{array}{l}20.03 \\
(21.10)\end{array}$ & $\begin{array}{c}5.563 \\
(20.66)\end{array}$ \\
\hline SIZENET & $\begin{array}{c}-0.0000466 \\
(0.000134)\end{array}$ & $\begin{array}{c}-0.0000742 \\
(0.000156)\end{array}$ & $\begin{array}{l}-0.000105 \\
(0.000150)\end{array}$ & $\begin{array}{c}-0.0000472 \\
(0.000138)\end{array}$ & $\begin{array}{r}-0.0000517 \\
(0.000130)\end{array}$ \\
\hline SIZEMARKET & $\begin{array}{c}-0.0000432 \\
(0.000028)\end{array}$ & $\begin{array}{c}-0.0000392 \\
(0.000028)\end{array}$ & $\begin{array}{c}-0.0000338 \\
(0.000027)\end{array}$ & $\begin{array}{c}-0.0000373 \\
(0.000027)\end{array}$ & $\begin{array}{c}-0.0000451 \\
(0.000027)\end{array}$ \\
\hline SIZESEGMENT & $\begin{array}{l}0.0152^{* * *} \\
(0.00372)\end{array}$ & $\begin{array}{l}0.0148^{* * *} \\
(0.00371)\end{array}$ & $\begin{array}{l}0.0135^{* * *} \\
(0.00368)\end{array}$ & $\begin{array}{l}0.0134^{* * *} \\
(0.00374)\end{array}$ & $\begin{array}{l}0.0145^{* * *} \\
(0.00369)\end{array}$ \\
\hline SUBSTITUTE & $\begin{array}{l}0.415^{*} \\
(0.176)\end{array}$ & $\begin{array}{l}0.386^{*} \\
(0.177)\end{array}$ & $\begin{array}{c}0.324 \\
(0.175)\end{array}$ & $\begin{array}{c}0.304 \\
(0.178)\end{array}$ & $\begin{array}{l}0.428^{*} \\
(0.177)\end{array}$ \\
\hline INITRAIN & $\begin{array}{l}0.659^{* *} \\
(0.214)\end{array}$ & $\begin{array}{l}0.609^{* *} \\
(0.213)\end{array}$ & $\begin{array}{l}0.586^{* *} \\
(0.210)\end{array}$ & $\begin{array}{l}0.545^{*} \\
(0.214)\end{array}$ & $\begin{array}{l}0.680^{* *} \\
(0.215)\end{array}$ \\
\hline TRANSF & $\begin{array}{l}0.793^{* *} \\
(0.244)\end{array}$ & $\begin{array}{l}0.709^{* *} \\
(0.247)\end{array}$ & $\begin{array}{l}0.646^{* *} \\
(0.250)\end{array}$ & $\begin{array}{l}0.712^{* *} \\
(0.238)\end{array}$ & $\begin{array}{l}0.759^{* *} \\
(0.246)\end{array}$ \\
\hline SERVICE & $\begin{array}{l}0.268^{*} \\
(0.137)\end{array}$ & $\begin{array}{c}0.240 \\
(0.138)\end{array}$ & $\begin{array}{c}0.200 \\
(0.137)\end{array}$ & $\begin{array}{c}0.128 \\
(0.139)\end{array}$ & $\begin{array}{c}0.223 \\
(0.135)\end{array}$ \\
\hline UPSUBSTI & $\begin{array}{l}0.131^{* * *} \\
(0.0284)\end{array}$ & $\begin{array}{l}0.136^{* * *} \\
(0.0284)\end{array}$ & $\begin{array}{l}0.136^{* * *} \\
(0.0279)\end{array}$ & $\begin{array}{l}0.126^{* * *} \\
(0.0281)\end{array}$ & $\begin{array}{l}0.122^{* * *} \\
(0.0284)\end{array}$ \\
\hline DOWNSUBSTI & $\begin{array}{l}-0.0647 \\
(0.0618)\end{array}$ & $\begin{array}{l}-0.0788 \\
(0.0631)\end{array}$ & $\begin{array}{c}-0.108 \\
(0.0622)\end{array}$ & $\begin{array}{c}-0.100 \\
(0.0601)\end{array}$ & $\begin{array}{c}-0.110 \\
(0.0605)\end{array}$ \\
\hline SOUTHEAST & $\begin{array}{l}-0.356 \\
(0.188)\end{array}$ & $\begin{array}{l}-0.392^{*} \\
(0.191)\end{array}$ & $\begin{array}{l}-0.353 \\
(0.192)\end{array}$ & $\begin{array}{l}-0.342 \\
(0.190)\end{array}$ & $\begin{array}{l}-0.295 \\
(0.188)\end{array}$ \\
\hline SOUTHWEST & -0.375 & -0.365 & -0.367 & -0.278 & -0.332 \\
\hline
\end{tabular}




\begin{tabular}{lccccc}
\hline & $(0.223)$ & $(0.226)$ & $(0.224)$ & $(0.226)$ & $(0.224)$ \\
NORTHEAST & -0.129 & -0.135 & -0.133 & -0.252 & -0.0796 \\
& $(0.211)$ & $(0.213)$ & $(0.207)$ & $(0.211)$ & $(0.206)$ \\
NORTHWEST & $-0.720^{* * *}$ & $-0.760^{* * *}$ & $-0.787^{* * *}$ & $-0.760^{* * *}$ & $-0.716^{* * *}$ \\
& $(0.204)$ & $(0.204)$ & $(0.200)$ & $(0.207)$ & $(0.202)$ \\
cons & & & & $-2.561^{* * *}$ \\
& $-2.961^{* * *}$ & $-3.142^{* * *}$ & $-2.594^{* * *}$ & $-2.588^{* * *}$ & $(0.431)$ \\
& $(0.450)$ & $(0.457)$ & $(0.431)$ & $(0.427)$ & 0.0000 \\
\hline Prob> chi2 & & & & 0.2220 \\
Pseudo R ${ }^{2} \%$ & 0.0000 & 0.0000 & 0.0000 & 0.0000 & 72.69 \\
Predicted & 0.2385 & 0.2464 & 0.2271 & 0.2451 & 0.8000 \\
\hline Area under ROC curve & 74.16 & 72.27 & 71.22 & 73.11 & 0.8132 \\
\hline
\end{tabular}

Standard errors in brackets

${ }^{*} p<0.05,{ }^{* *} p<0.01,{ }^{* * *} p<0.001$

CAPITALCITY is the reference for the location of the upstream unit.

The results are robust and qualitatively similar to those of another reference.

These estimates enable us, first, to comment on the quality of the econometric models. The good global significance of the models is highlighted by the pseudo R-squared, which is quite high for cross-sectional data (between 0.11 and 0.27), by the chi-square probabilities, which are systematically equal to 0 , by the percentage predicted (between 68.28 and 74.16), and by the area under the receiver operating characteristic (ROC) curve (between 0.80 and 0.82 ).

The comparison of the estimated models shows that the results are robust.

Regarding the control variables, the results suggest that the age of the network and the type of network have no influence on the decision to impose ED. The probability for ED is higher when the upstream unit operates a single-branded network. This result supports the argument of Besanco and Perry (1993), in which an ED contract can be used to eliminate the inter-brand externality of the upstream firms when the inter-brand competition is strong. Interesting results are obtained concerning the impact of the other vertical restraints (exclusive territory, tying) and of the geographical location of the upstream structure (head-ends) such that the probability for ED is higher when the vertical contract encloses other vertical restraints. In addition, the results highlight the influence of geographical features. More precisely, the probability for ED is higher when the upstream unit is located in the area of the capital city (models 1 to 4). Furthermore, when using CAPITALCITY as the reference, the probability for ED is lower when the upstream unit of the network is located in the northwest of France.

The core explanatory variables are first concerned with the upstream competition. While the market share of the network, the Herfindahl-Hirschmann index, and the interaction of these two variables have no influence on the decision to $\mathrm{ED}$, the size of the market segment exerts a 
significant positive influence.

Regarding downstream competition, the number of retail units has no significant influence regarding the intra-brand downstream competition (SIZENET) or the intra- and inter-brand competition (SIZEMARKET). However, the results suggest that the type of product affects the choice for ED (SUBSTITUTE), even if the sign is the reverse of that which is predicted.

Finally, estimates dealing with investment issues highlight the relationship between the upstream investments, either complementary or substitutable, and ED. In all cases (INITRAIN, TRANSF, UPSUBSTI), the sign is positive, that is, it is the reverse of the prediction concerning the upstream substitutable investments. On the other hand, we do not find evidence regarding the influence of downstream investments on ED.

\subsection{Endogeneity and robustness checks}

Endogeneity problems can be suspected regarding the variables OTHERNET, EXCLUTERRI, TYING, TYPENET, DOWNSTREAMSI compared to other vertical restraints (EXCLUTERRI, TYING, DOWNSTREAMSI) or to strategic choices of the upstream unit (OTHERNET, TYPENET).

For this reason, we perform Hausman tests comparing probit and bivariate probit models fitted to binary endogenous regressors. The results show that it is not possible to conclude for endogeneity regarding OTHERNET (critical probability ${ }^{4}$ : Prob $>$ chi2 $=0.2485$ ), EXCLUTERRI (critical probability: Prob>chi2 $=0.2925)$, TYPENET (critical probability: Prob $>$ chi2 $=0.2951$ ) or DOWNSTREAMSI (critical probability: Prob>chi2 $=0.2016$ ).

A low risk of endogeneity is highlighted regarding TYING (critical probability: Prob $>$ chi2 = 0.0946). For this reason, we provide the estimation results of bivariate probit models (11 and 12) and seemingly unrelated bivariate probit models with sector dummies (13 and14), thus controlling for the potential endogeneity of this variable (Table 12). The estimates are qualitatively similar to the other estimation results.

\footnotetext{
${ }^{4}$ The null hypothesis $\mathrm{H}_{0}$ is the hypothesis of exogeneity.
} 
Table 12. Bivariate probit and seemingly unrelated bivariate probit estimates for exclusive dealing (potential endogeneity of TYING)

\begin{tabular}{|c|c|c|c|c|}
\hline & (11) & $(12)$ & (13) & (14) \\
\hline $\begin{array}{l}\text { Dependent variable: ED } \\
\text { SOUTHEAST }\end{array}$ & $\begin{array}{l}-0.295 \\
(0.182)\end{array}$ & & $\begin{array}{l}-0.337 \\
(0.183)\end{array}$ & \\
\hline SOUTHWEST & $\begin{array}{l}-0.356 \\
(0.204)\end{array}$ & & $\begin{array}{l}-0.284 \\
(0.220)\end{array}$ & \\
\hline NORTHEAST & $\begin{array}{l}-0.139 \\
(0.198)\end{array}$ & & $\begin{array}{l}-0.238 \\
(0.222)\end{array}$ & \\
\hline NORTHWEST & $\begin{array}{c}-0.772^{* * *} \\
(0.194)\end{array}$ & & $\begin{array}{c}-0.728^{* * *} \\
(0.219)\end{array}$ & \\
\hline CAPITALCITY & & $\begin{array}{l}0.384^{* *} \\
(0.133)\end{array}$ & & $\begin{array}{l}0.387^{* *} \\
(0.142)\end{array}$ \\
\hline MARKETSHARE & $\begin{array}{l}-0.313 \\
(1.397)\end{array}$ & $\begin{array}{l}-0.627 \\
(1.413)\end{array}$ & $\begin{array}{l}0.0935 \\
(1.517)\end{array}$ & $\begin{array}{l}-0.152 \\
(1.462)\end{array}$ \\
\hline $\mathrm{HHI}$ & $\begin{array}{l}0.00682 \\
(0.0125)\end{array}$ & $\begin{array}{l}0.00796 \\
(0.0124)\end{array}$ & $\begin{array}{l}0.00273 \\
(0.0137)\end{array}$ & $\begin{array}{l}0.00323 \\
(0.0135)\end{array}$ \\
\hline MARKSHARHHI & $\begin{array}{c}10.42 \\
(20.24)\end{array}$ & $\begin{array}{l}16.30 \\
(20.51)\end{array}$ & $\begin{array}{l}18.91 \\
(21.96)\end{array}$ & $\begin{array}{c}22.44 \\
(21.26)\end{array}$ \\
\hline SIZESEGMENT & $\begin{array}{l}0.0132^{* * *} \\
(0.00361)\end{array}$ & $\begin{array}{l}0.0123^{* * *} \\
(0.00357)\end{array}$ & $\begin{array}{l}0.0124^{* *} \\
(0.00422)\end{array}$ & $\begin{array}{l}0.0109^{* *} \\
(0.00410)\end{array}$ \\
\hline SIZENET & $\begin{array}{l}-0.000105 \\
(0.000146)\end{array}$ & $\begin{array}{l}-0.000108 \\
(0.000152)\end{array}$ & $\begin{array}{r}-0.0000460 \\
(0.000180)\end{array}$ & $\begin{array}{r}-0.0000489 \\
(0.000178)\end{array}$ \\
\hline SIZEMARKET & $\begin{array}{l}-0.0000331 \\
(0.0000263)\end{array}$ & $\begin{array}{l}-0.0000286 \\
(0.0000262)\end{array}$ & $\begin{array}{l}-0.0000348 \\
(0.0000273)\end{array}$ & $\begin{array}{l}-0.0000301 \\
(0.0000269)\end{array}$ \\
\hline SUBSTITUTE & $\begin{array}{c}0.334 \\
(0.171)\end{array}$ & $\begin{array}{c}0.305 \\
(0.169)\end{array}$ & $\begin{array}{c}0.253 \\
(0.197)\end{array}$ & $\begin{array}{c}0.206 \\
(0.191)\end{array}$ \\
\hline INITRAIN & $\begin{array}{l}0.484^{*} \\
(0.194)\end{array}$ & $\begin{array}{l}0.501^{* *} \\
(0.189)\end{array}$ & $\begin{array}{l}0.537^{* *} \\
(0.206)\end{array}$ & $\begin{array}{l}0.535^{* *} \\
(0.203)\end{array}$ \\
\hline TRANSF & $\begin{array}{l}0.675^{* *} \\
(0.227)\end{array}$ & $\begin{array}{l}0.672^{* *} \\
(0.227)\end{array}$ & $\begin{array}{l}0.709^{* *} \\
(0.232)\end{array}$ & $\begin{array}{l}0.685^{* *} \\
(0.227)\end{array}$ \\
\hline SERVICE & $\begin{array}{c}0.222 \\
(0.129)\end{array}$ & $\begin{array}{c}0.235 \\
(0.128)\end{array}$ & $\begin{array}{c}0.148 \\
(0.141)\end{array}$ & $\begin{array}{c}0.160 \\
(0.136)\end{array}$ \\
\hline UPSUBSTI & $\begin{array}{l}0.141^{* * *} \\
(0.0264)\end{array}$ & $\begin{array}{l}0.139^{* * *} \\
(0.0258)\end{array}$ & $\begin{array}{l}0.123^{* * *} \\
(0.0290)\end{array}$ & $\begin{array}{l}0.119^{* * *} \\
(0.0290)\end{array}$ \\
\hline DOWNSUBSTI & $\begin{array}{l}-0.0696 \\
(0.0577)\end{array}$ & $\begin{array}{l}-0.0687 \\
(0.0571)\end{array}$ & $\begin{array}{l}-0.0980 \\
(0.0600)\end{array}$ & $\begin{array}{l}-0.0959 \\
(0.0591)\end{array}$ \\
\hline AGE & & & $\begin{array}{l}-0.00271 \\
(0.00330)\end{array}$ & $\begin{array}{l}-0.00264 \\
(0.00323)\end{array}$ \\
\hline TYING & & & 0.975 & $1.142^{*}$ \\
\hline
\end{tabular}




\begin{tabular}{|c|c|c|c|c|}
\hline _cons & $\begin{array}{c}-2.401^{* * *} \\
(0.397)\end{array}$ & $\begin{array}{c}-2.806^{* * *} \\
(0.388)\end{array}$ & $\begin{array}{c}(0.574) \\
\\
-2.731^{* * *} \\
(0.471)\end{array}$ & $\begin{array}{c}(0.491) \\
-3.166^{* * *} \\
(0.426)\end{array}$ \\
\hline $\begin{array}{l}\text { Dependent variable: TYING } \\
\text { Similar independent variables and } \\
\text { equations for ED }\end{array}$ & yes & yes & no & no \\
\hline Sector dummies & no & no & yes & yes \\
\hline Prob $>$ chi2 & 0.0000 & 0.0000 & 0.0000 & 0.0000 \\
\hline
\end{tabular}

Standard errors in brackets

${ }^{*} p<0.05,{ }^{* *} p<0.01,{ }^{* * *} p<0.001$

Finally, the inclusion of sector dummies in the probit models allows checking for the robustness of the results, which are, again, qualitatively similar, with the exception of the variable SUBSTITUTE, as highlighted in Table 13.

Table 13. Probit estimates for exclusive dealing with sector dummies

\begin{tabular}{|c|c|c|c|c|c|}
\hline & $(15)$ & $(16)$ & $(17)$ & $(18)$ & (19) \\
\hline AGE & $\begin{array}{r}-0.000561 \\
(0.00382)\end{array}$ & $\begin{array}{r}-0.000591 \\
(0.00388)\end{array}$ & $\begin{array}{r}-0.000357 \\
(0.00393)\end{array}$ & $\begin{array}{l}0.000115 \\
(0.00383)\end{array}$ & $\begin{array}{r}-0.000576 \\
(0.00387)\end{array}$ \\
\hline OTHERNET & $\begin{array}{c}0.244^{* *} \\
(0.0768)\end{array}$ & $\begin{array}{c}0.233^{* *} \\
(0.0772)\end{array}$ & & & \\
\hline EXCLUTERRI & & $\begin{array}{l}0.416^{*} \\
(0.165)\end{array}$ & $\begin{array}{l}0.444^{* *} \\
(0.163)\end{array}$ & & \\
\hline TYING & & & & $\begin{array}{c}0.581^{* * *} \\
(0.154)\end{array}$ & \\
\hline TYPENET & & & & & $\begin{array}{c}0.0527 \\
(0.0480)\end{array}$ \\
\hline CAPITALCITY & $\begin{array}{l}0.343^{*} \\
(0.148)\end{array}$ & $\begin{array}{c}0.369^{*} \\
(0.151)\end{array}$ & $\begin{array}{l}0.355^{*} \\
(0.150)\end{array}$ & $\begin{array}{l}0.348^{*} \\
(0.151)\end{array}$ & $\begin{array}{l}0.307^{*} \\
(0.147)\end{array}$ \\
\hline SIZESEGMENT & $\begin{array}{c}0.00433 \\
(0.00667)\end{array}$ & $\begin{array}{c}0.00162 \\
(0.00673)\end{array}$ & $\begin{array}{l}-0.00172 \\
(0.00648)\end{array}$ & $\begin{array}{c}0.00105 \\
(0.00660)\end{array}$ & $\begin{array}{c}0.00127 \\
(0.00646)\end{array}$ \\
\hline SUBSTITUTE & $\begin{array}{c}0.241 \\
(0.424)\end{array}$ & $\begin{array}{c}0.148 \\
(0.416)\end{array}$ & $\begin{array}{c}0.286 \\
(0.402)\end{array}$ & $\begin{array}{c}0.186 \\
(0.412)\end{array}$ & $\begin{array}{c}0.472 \\
(0.418)\end{array}$ \\
\hline INITRAIN & $\begin{array}{c}0.745^{\text {****}} \\
(0.209)\end{array}$ & $\begin{array}{c}0.695^{* * *} \\
(0.211)\end{array}$ & $\begin{array}{l}0.677^{* *} \\
(0.210)\end{array}$ & $\begin{array}{l}0.648^{* *} \\
(0.210)\end{array}$ & $\begin{array}{c}0.750^{* * *} \\
(0.210)\end{array}$ \\
\hline TRANSF & $\begin{array}{c}0.822^{* * *} \\
(0.238)\end{array}$ & $\begin{array}{l}0.723^{* *} \\
(0.245)\end{array}$ & $\begin{array}{l}0.679^{* *} \\
(0.246)\end{array}$ & $\begin{array}{l}0.738^{* *} \\
(0.236)\end{array}$ & $\begin{array}{c}0.797^{* * *} \\
(0.236)\end{array}$ \\
\hline SERVICE & $0.329^{*}$ & $0.308^{*}$ & 0.269 & 0.157 & $0.283^{*}$ \\
\hline
\end{tabular}




\begin{tabular}{|c|c|c|c|c|c|}
\hline & $(0.139)$ & $(0.140)$ & $(0.138)$ & $(0.143)$ & $(0.137)$ \\
\hline UPSUBSTI & $\begin{array}{l}0.118^{* * *} \\
(0.0287)\end{array}$ & $\begin{array}{l}0.123^{* * *} \\
(0.0288)\end{array}$ & $\begin{array}{c}0.123^{* * *} \\
(0.0283)\end{array}$ & $\begin{array}{l}0.117^{* * *} \\
(0.0285)\end{array}$ & $\begin{array}{l}0.113^{* * *} \\
(0.0286)\end{array}$ \\
\hline DOWNSUBSTI & $\begin{array}{c}0.0110 \\
(0.0651)\end{array}$ & $\begin{array}{c}-0.000151 \\
(0.0657)\end{array}$ & $\begin{array}{l}-0.0245 \\
(0.0641)\end{array}$ & $\begin{array}{l}-0.0131 \\
(0.0629)\end{array}$ & $\begin{array}{l}-0.0256 \\
(0.0636)\end{array}$ \\
\hline Sector dummies & yes & yes & yes & yes & yes \\
\hline Prob $>$ chi2 & 0.0000 & 0.0000 & 0.0000 & 0.0000 & 0.0000 \\
\hline Pseudo $R^{2}$ & 0.2594 & 0.2688 & 0.2549 & 0.2663 & 0.2457 \\
\hline$\%$ Predicted & 73.94 & 72.88 & 74.15 & 72.46 & 73.52 \\
\hline Area under ROC curve & 0.8181 & 0.8243 & 0.8208 & 0.8227 & 0.8116 \\
\hline
\end{tabular}

Standard errors in brackets

${ }^{*} p<0.05,{ }^{* *} p<0.01,{ }^{* * *} p<0.001$

Models with sector dummies do not include HHI indexes.

\subsection{Interpretation of the results}

Summary comments are provided concerning the testable predictions subjected to data for analysis.

Regarding the first hypothesis (H1), which predicts a positive influence of the concentration on the occurrence of an ED contract, our results suggest a reverse relationship. More precisely, when the subsectors are taken into account, we find that the size of the market segment is positively related to the likelihood of ED.As the size of the market segment indicates the number of upstream firms within a subsector of the sample, the result suggests a positive relationship between the number of upstream firms and the likelihood of ED. Hence, the hypothesis H1, in which anti-competitive ED is more likely to occur for more concentrated upstream industries, does not hold. In other words, the French distribution data do not support the anti-competitive rationale that $\mathrm{ED}$ is used by dominant upstream firms to foreclose the trade of potential competitors with downstream retailers. Therefore, our results provide evidence that the ED contract used in the French distribution network is mainly for the purpose of improving efficiency. Indeed, as suggested in Kitamura (2010), "if ED is signed in industries with many alternative factor inputs, products and technologies, then it is likely to be signed for efficiency reasons".

Our empirical findings regarding $H 1$ are complemented and enhanced by the results concerning the geographical location of the upstream units. To understand explain the impact of the geographical dimension and, more precisely, the positive influence of the location in the capital city on the choice to use ED, we suspect a link between geographical features and the 
level of upstream competition. Simple statistics as those provided in Appendix 2 confirm this relationship. First, we see that the number of networks with an upstream unit located in the capital city is higher (Table 15). Considering the empirical finding that when the upstream unit is located in the capital city the likelihood for ED is higher, the results suggests that the upstream competition level positively impacts the choice for $\mathrm{ED}$, which is contrary to the anti-competitive argument. To study the robustness of the link between the geographical location and the level of competition, we perform Pearson chi-square tests between the location of the upstream unit and several competition variables. All results clearly show that the hypothesis of independence must be rejected. In other words, whatever the competition criteria (number of units, networks or outlets in the sector or the segment, etc.), there is a statistical dependence between the location of the upstream unit and the level of competition (Table 16).

Regarding downstream competition, we do not find evidence that the number of downstream units for each network (intra-brand downstream competition) or for each market (intra- and inter-brand downstream competition) impact the choice for ED (H2a). However, our empirical results in models 4, 5, 6, 7 and 10 suggest that the more substitutable the products, the lower the probability of observing $\mathrm{ED}$, which is precisely the reverse of $H 2 b$. Analogous to the analysis of the upstream competition, when the downstream competition is taken into account, our results do not support the anti-competitive motive of using ED, a finding that is consistent with Simpson and Wickelgren (2007), Wright (2009), etc. ${ }^{5}$ Thus, it appears that in the French distribution system, ED is used neither to exploit contract externality of buyers when buyers are difficult to coordinate (i.e., retailers are numerous), nor to restore monopoly power when intensive downstream competition squeezes the vertical industry profit.

In addition, our results provide empirical support for $\mathrm{H}_{3}$ a regarding the positive relationship of the upstream complementary investments and the likelihood of observing ED. The results show that the upstream substitutable investments also relate positively to the choice for ED. This last result is contrary to $H 3 b$. Finally, we do not find evidence for hypotheses $H 4 a$ and $H 4 b$, which are related to the downstream investments.

To summarise, it appears that only upstream investments, whether they are complementary or substitutable, impact the choice for ED. In both cases, we find evidence that the more the upstream firm invests in the vertical relationship, the more likely the firm is to sign ED contracts

\footnotetext{
${ }^{5}$ Noting that Fumagalli and Motta (2006) and (2008) suggest that the anti-competitive ED is more likely to occur if downstream products are substitutable. However, their analysis is based on the assumption of harsh, Bertrand-like downstream competition in which buyers are driven out of the market if they bear higher wholesale prices from the less efficient incumbent. This assumption seems to be less consistent with the French distribution network, as many retail stores are horizontally differentiated and are not easily driven out if their competitors have cheaper supply sources.
} 
with downstream retailers. This result suggests that the suppliers do not distinguish between the different types of investments and that they tend to impose more restrictive contractual clauses because their level of involvement in the vertical relationship is higher.

The efficiency motive of ED finds strong support when we take into account the nature of the investment. The fact that both complementary and substitutable investments by upstream suppliers are positively related with the adoption of an ED contract suggests that ED can be used to foster the upstream investment. As investigated by Segal and Whinston (2000b), the upstream complementary investments, such as efforts for training the downstream staffs and the transmission of knowledge, also benefit the trade between retailers and competitors. Therefore, ED can be used to protect the investment from free-riding by the upstream competitors. In this case, ED is efficiency improving. A similar explanation can also be found in Besanko and Perry (1993), where investment has a positive inter-brand externality to the competitor's chain.

However, when the upstream investment is substitutable, in that it reduces the value of trade between the retailers and the upstream competitors, Segal and Whinston (2000b) find that the investment incentive of the supplier tends to be higher in the absence of $\mathrm{ED}$, as the exclusive contract can worsen the position of the upstream competitors with investments. This rationale is obviously anti-competitive. However, as our empirical finding regarding $H 3 b$ suggests a reverse result, it again appears that the anti-competitive rationale for ED does not hold in the French case.

\section{Conclusions}

This paper investigates the rationales of ED, which is one of the most common forms of vertical restraint, in attracting intense policy debates in anti-trust regulations. Based on a survey of the theoretical literature, we identify the determinants that may result in this contractual arrangement for anti-competitive and pro-competitive reasons. In particular, we consider the industry features, such as the upstream and downstream competition, as well as the nature of the investments undertaken in the vertical relationship. Several hypotheses are derived from the theoretical framework and tested using French data from several types of distribution networks in a wide range of sectors.

The results highlight the good explanatory power of the estimated probit models (good fit statistics). These results are robust and suggest that taking into account the market structure and the upstream and downstream investment nature, ED contracts are primarily used for procompetitive reasons in the French distribution system. More precisely, we find that contrary to 
the theoretical prediction regarding the anti-competitive rationales of $\mathrm{ED}$, the larger the number of upstream firms within a subsector of the sample, the more likely these firms are to reach ED agreements with downstream retailers. Meanwhile, there is no evidence that the number of downstream units for each network (intra-brand downstream competition) or for each market (intra- and inter-brand downstream competition) affects the choice for ED. Instead, we find that the more substitutable the final products are, the more likely it is that there will be ED contracts. Therefore, it appears that in the French distribution networks, ED is used neither to exploit contract externality of buyers when buyers are difficult to coordinate (i.e.. when retailers are numerous) nor to restore the monopoly power when intensive downstream competition squeezes the vertical industry profit.

It seems that the motivation for ED is primarily the result of its positive role in fostering the investment of the upstream firms. Indeed, we find that the more the upstream firms invest in the vertical relationship, the more likely that they sign ED contracts, a finding that corresponds to the theoretical prediction on the efficient motive of ED (Segal and Whinston 2000b, Besanko and Perry 1993): the upstream investments, such as efforts for training the downstream staffs and the transmission of expertise, also benefit the trade between retailers and competitors. Therefore, ED can be used to protect the investment from the free-riding of the upstream competitors.

Our empirical results provide interesting insights for competition authorities. The traditional regulation of the competition agencies is usually hostile towards ED agreements. As noted by Motta et al. (2012), "The decisions in cases involving ED are often controversial as the promotion of relation-specific investment must be balanced against the threat of foreclosure of potential competitors". Our results suggest that when an industry or a sector is taken into account, ED exhibits a pro-competitive nature in promoting the relation-specific investment, rather than enhancing the dominant position of the incumbent. The reason can stem from two facts. On the one hand, our results may suggest that the competition authority has successfully blocked the anti-competitive ED, leaving the pro-efficiency ED prevailing in the industry. On the other hand, the results may imply that the studied industry structures and the market environments are unfavourable for anti-competitive ED. This second interpretation of our empirical findings is consistent with the critics of the Chicago School (Bork, 1978 and Posner, 1976) who contend the incumbent would not find it profitable to sign an anti-competitive ED contract and to pay buyers not to address the efficient entrant.

As the first explanation raises a problem of selection bias, future studies in this direction would be interesting. Other limits of this paper include the definition of the dummy variable capturing the product level of substitution and the identification of the nature of the investments, 
which may be not well specified. Here, again, complementary empirical results would be useful in dealing with such variables.

Finally, our results regarding the control variables open interesting avenues for further study.

While the age and the type of the network have no influence on the choice to include an ED clause, a strong influence of the geographical location of the upstream firm must be noted. This is an unexplored, yet interesting, dimension of the contractual choices, and the result is robust in this respect. Thus, the choice to impose ED differs regarding the location of the upstream unit, with a main distinction between the capital city area and the rest of the country. The statistical link between the geographical location and the level of the upstream competition, as highlighted in the paper, is a first step in the explanation. The impact of the geographical dimension on the contractual design and, more broadly, on the organisational choices in distribution networks appears as a new and interesting direction for future research.

In addition, our estimations highlight also the strong influence of the other vertical restraints (exclusive territory, tying) on the choice to impose ED. Regarding this issue, we control for endogeneity bias with Hausman tests comparing probit and bivariate probit models fitted to binary endogenous regressors. The estimated positive influence provides evidence of the complementarity between the vertical restraints, thus suggesting that the three studied provisions (ED, tying, exclusive territory) can be considered a "package". This result also calls for further empirical research regarding the interactions between the vertical restraints used in distribution contracts.

\section{References}

Abito, J.M. and J. Wright, 2008, "Exclusive dealing with imperfect downstream competition", International Journal of Industrial Organization, 26: 227-246.

Aghion, P. and P. Bolton, 1987, "Contracts as a Barrier to Entry", American Economic Review, 77: 388-401.

Asker, J., 2004, "Measuring Cost Advantages from Exclusive Dealing An Empirical Study of Beer Distribution," mimeo, Dept. of Economics, Harvard University.

Asker, J., 2005, "Diagnosing Foreclosure due to Exclusive Dealing", mimeo, Dept. of Economics, Harvard University.

Asker, J. and B.I. Heski, 2013, “Raising Retailer's Profits: On Vertical Practices and the Exclusion of Rivals", American Economic Review, Forthcoming. 
Ater, I., 2010, "Vertical Foreclosure using Exclusive Dealing: The Case of Hamburger Restaurants in Shopping Malls", Working Paper, Tel Aviv University.

Berheim, B.D. and M.D. Whinston, 1998, "Exclusive Dealing", Journal of Political Economy, 106, 1: 64-103.

Besanko, D., Perry, M.K., 1993, "Equilibrium Incentives for Exclusive Dealing in a Differentiated Products Oligopoly", Rand Journal of Economics, 24: 646-667.

Bork, R., 1978, The Antitrust Paradox, New York: Basic Books.

Brenkers R. and Verboven F., 2006, "Liberalizing a Distribution System: the European Car Market", Journal of the European Economic Association,4: 216-251.

Brickley, J.A., 1999, "Incentive conflicts and contractual restraints: evidence from franchising", Journal of Law and Economics, 42: 745-774.

European Commission, 2010, Guidelines on Vertical Restraints, Official Journal of the European Union No. C 130 (2010/C130/01).

Fumagalli C., Motta M., and L. Persson, 2009, "On the anticompetitive effect of exclusive dealing when entry by merger is possible", The Journal of Industrial Economics, 57, 4: 785-811.

Fumagalli, C. and M. Motta, 2006, "Exclusive Dealing and Entry, When Buyers Compete", American Economic Review, 96, 3: 785-795.

Fumagalli, C. and M. Motta, 2008. "Buyers. Miscoordination, Entry and Downstream Competition”, Economic Journal, 118, 531: 1196-1222.

Fumagalli, C., Motta, M. and T. Rønde, 2009. "Exclusive Dealing: The Interaction between Foreclosure and Investment Promotion", Working Paper 2009.120, FondazioneEni Enrico Mattei.

Fumagalli C., Motta M., Rønde T., 2012. "Exclusive dealing: investment promotion may facilitate inefficient foreclosure", Journal of Industrial Economics, 60, 4: 599-608.

Gratz, L. and M. Reisinger, 2013, "On the Competition Enhancing Effects of Exclusive Dealing Contracts”, International Journal of Industrial Organization, forthcoming.

Gorecki, Paul K,2006, "Form-Versus Effects-Based Approaches to the Abuse of a Dominant Position: The Case of Ticketmaster Ireland", Journal of Competition Law and Economics,2(3),533-548.

Heide J.B., Dutta S., and M. Bergen, 1998, "Exclusive Dealing and Business Efficiency: Evidence from Industry Practice", Journal of Law and Economics, 41: 387-407.

Hiller S., 2012, "Exclusive Dealing and Its Effects: The Impact of Large Music Festivals on Local Music Venues", Working Paper, University of Colorado.

Innes, R. andR.J. Sexton, 1994, "Strategic Buyers and Exclusionary Contracts", American Economic Review, 84, 3: 566-584.

Karlinger L., Motta M., 2007, "Exclusionary Pricing and Rebates When Scale Matters", CEPR 
Discussion Paper No. DP6258.

Karlinger L., and M. Motta, 2012, "Exclusionary pricing when scale matters", The Journal of Industrial Economics, LX,1: 75-103.

Kitamura, H. 2010, "Exclusionary vertical contracts with multiple entrants", International Journal of Industrial Organization, 28: 213-219.

Klick J. and J.D. Wright, 2008, “The Effects of Vertical Restraints on Output: Evidence from the Beer Industry", Manuscript.

Lafontaine F. and Slade M., 2007,"Vertical Integration and Firm Boundaries: The Evidence", Journal of Economic Literature, 45,3: 631-687.

Lafontaine F. and Slade M., 2008, "Exclusive Contracts and Vertical Restraints: Empirical Evidence and Public Policy", Handbook of Antitrust Economics, Paolo Buccirossi (ed.) Cambridge: MIT Press, 391-414.

LafontaineF. and Slade M., 2012, "Inter-Firm Contracts: Evidence”, Handbook of Organizational Economics, R. Gibbons and J. Roberts (eds.), Princeton University Press, 958-1013.

Lafontaine F. and Slade M., 2013, "Franchising and Exclusive Distribution: Adaptation and Antitrust", in Oxford Handbook of International Antitrust, R. Blair and D. Sokol (eds.), Oxford University Press, Forthcoming.

Mortimer J.H., 2008, "Vertical Contracts in the Video Rental Industry, "Review of Economic Studies, 75, 1:165-199.

Motta, M. 2004, Comptetition Policy, Cambridge University Press, Chapter 6.

Nurski L., and Verboven F., 2011, "Exclusive Dealing as a Barrier to Entry? Evidencefrom Automobiles, Mimeo, University of Leuven.

Posner, R.A., 1976, Antitrust Law: An Economic Perspective, Chicago: University of Chicago Press.

Rasmusen, E.B., Ramseyer J.M., Wiley J.S., 1991, "Naked Exclusion”, American Economic Review, $81,1137-45$.

Sass T.R., 2005, "The Competitive Effects of Exclusive Dealing: Evidence from the US Beer Industry", International Journal of Industrial Organization, 23: 203225.

Segal, I.R., Whinston, M.D., 2000a, "Naked Exclusion: Comment", American Economic Review, 90, 296-309.

Segal, I.R., Whinston, M.D., 2000b, "Exclusive Contracts and Protection of Investment", Rand Journal of Economics, 31, 603-33.

Simpson, J. and A.L.Wickelgren, 2007, "Naked Exclusion, Efficient Breach, and Downstream Competition", American Economic Review, 97(4), 1305-1320.

Slade, M.E., 2000, "Regulating Manufacturers and their Exclusive Retailers," in Foundations 
of Competition Policy, Morten Berg and Einar Hope (eds.), London: Routledge, 133-149.

Slade, M.E., 2008, "The Effects of Vertical Restraints: An Evidence Based Approach", in The Pros and Cons of Vertical Restraints, Swedish Competition Authority.

Slade, M.E., 2011, Competition Policy Towards Brewing: Rational Response to Market Power or Unwarranted Interference in Well Functioning Markets? In The Economics of Beer, J. Swinnen (ed.) Oxford: Oxford University Press.

Spier, K.E. and M.D. Whinston, 1995, "On the efficiency of privately stipulated damages for breach of contract: entry barriers, reliance and renegotiation", Rand Journal of Economics, 26(2), 180-202.

Wen C.C, 2013, "Does Exclusive Dealing Matter? Evidence from Distribution Contract Changes in the U.S. Beer Industry", mimeo, National University of Taipei.

Wright J.D., 2009, "An evidence-based approach to exclusive dealing and Loyalty discounts", Working Paper, George Mason University Law and Economics, 09-32.

Appendix 1.

Table 14. Variance inflation factors

\begin{tabular}{|l|l|}
\hline \multicolumn{1}{|c|}{ Variable } & VIF \\
\hline SIZEMARKET & 4.72 \\
\hline SIZESEGMENT & 4.20 \\
\hline HHI & 3.16 \\
\hline MARKETSHARE & 2.91 \\
\hline MARKSHARHHI & 2.50 \\
\hline SUBSTITUTE & 2.01 \\
\hline TRANSF & 1.68 \\
\hline INITRAIN & 1.66 \\
\hline UPSUBSTI & 1.40 \\
\hline SOUTHWEST & 1.34 \\
\hline DOWNSUBSTI & 1.33 \\
\hline NORTHWEST & 1.33 \\
\hline SOUTHEAST & 1.30 \\
\hline TYING & 1.27 \\
\hline TYPENET & 1.26 \\
\hline NORTHEAST & 1.23 \\
\hline SERVICE & 1.22 \\
\hline EXCLUTERRI & 1.21 \\
\hline SIZENET & 1.17 \\
\hline AGE & 1.15 \\
\hline OTHERNET & 1.11 \\
\hline Mean VIF & 1.86 \\
\hline & \\
\hline
\end{tabular}


Appendix 2.

Figure 1. Visual abstract of the framework

French data (INSEE)

15 markets ie sectors, enclosing 25 segments (INSEE classifications)

On each market:

Upstream

Competing

firms

(Suppliers - S)
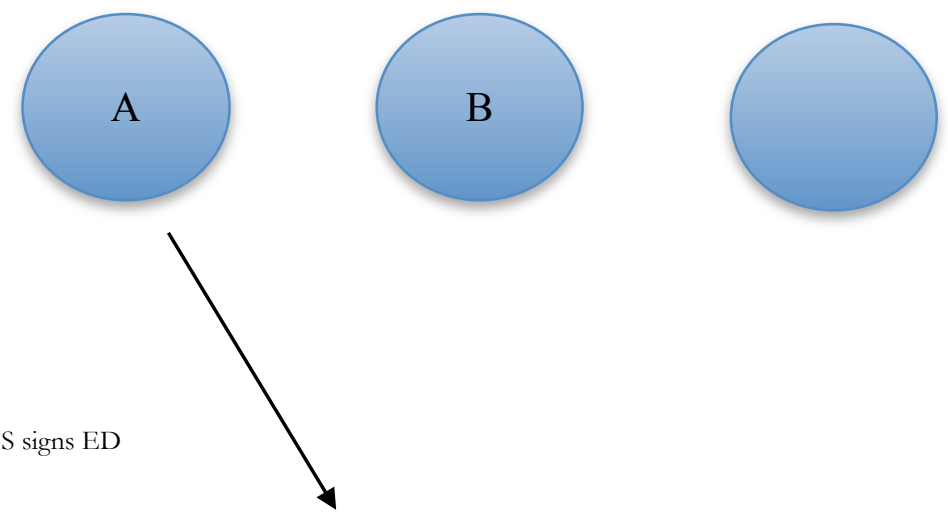

Downstream firms

competing

(Retailers)

Upstream iner-brand competition

Downstream inter \& intra brand competition

Final consumer not taken into account in the data

Network $=$ one upstream unit in addition with several retailers using a common brand.

Upstream unit:

$\checkmark$ defines and promotes the brand name

$\checkmark$ supplier

234 networks with ED

270 networks without ED

Without ED each downstream unit using the brand name of A can deal in the same time with B.

Research questions:

Why include ED in distribution contracts? Anti or pro competitive motivation? 


\section{Appendix 3.}

Table 15. Geographical distribution of the networks

\begin{tabular}{|c|c|}
\hline Location of the upstream unit & Number of networks \\
\hline Capital city & 209 \\
\hline Southeast & 93 \\
\hline Southwest & 63 \\
\hline Northeast & 60 \\
\hline Northwest & 79 \\
\hline
\end{tabular}

Table 16. Pearson chi-square tests

between the location of the upstream unit and competition variables

\begin{tabular}{|c|c|}
\hline $\begin{array}{l}\text { Variable } 1 . \\
\text { Location of the } \\
\text { upstream unit* }\end{array}$ & Pearson chi-square tests** \\
\hline $\begin{array}{r}\text { MARKET } \\
\text { Number of networks - } 15 \text { markets }\end{array}$ & Pearson chi2 $(44)=97.0215 \operatorname{Pr}=0.000$ \\
\hline $\begin{array}{r}\text { SIZESEGMENT } \\
\text { Number of networks - } 25 \text { segments }\end{array}$ & Pearson chi2 $(88)=164.5566 \operatorname{Pr}=0.000$ \\
\hline Interactive variable: MARKET * SIZESEGMENT & Pearson chi2 $(120)=191.2780 \operatorname{Pr}=0.000$ \\
\hline $\begin{array}{r}\text { SIZEMARKET } \\
\text { Number of downstream units }-15 \text { markets }\end{array}$ & Pearson chi2 $(56)=120.1059 \operatorname{Pr}=0.000$ \\
\hline
\end{tabular}

* 5 alternatives: Capital city, Southeast, Southwest, Northeast, Northwest.

** The null hypothesis $\mathrm{H} 0$ is the hypothesis of independence between variable $1 \&$ variable 2 .

This hypothesis is rejected in all the cases 